\title{
Wittgenstein, value pluralism and politics
}

\author{
Matthew J. Moore \\ California Polytechnic State University
}

\begin{abstract}
This article makes three main claims: (1) that the philosophy of Ludwig Wittgenstein, properly understood, has no normative or political implications whatsoever; (2) that scholars with otherwise dramatically conflicting interpretations of Wittgenstein should nonetheless all agree with this conclusion; and (3) that understanding the (non-) implications of Wittgenstein's philosophy helps to answer the two motivating questions of the literature on value pluralism whether values are (or can be) plural (yes), and whether value pluralism leads to, requires, or reveals some particular normative or political response (no).

The questions of whether the work of Ludwig Wittgenstein has any relevance to politics, and if so what that relevance might be, have evoked an astonishing variety of answers. ${ }^{1}$ There are commentators who see Wittgenstein as a Burkean conservative ${ }^{2}$ a radical democrat,${ }^{3}$ a Pyrrhonian skeptic, ${ }^{4}$ and a nihilist, ${ }^{5}$ to name only the most extreme positions. And these relatively contained debates over Wittgenstein and politics are themselves situated within a much larger set of debates about how to understand Wittgenstein’s writings (and whether 'understand' is the right word). ${ }^{6}$

One of the main debates in Wittgenstein interpretation over the past 20 years has been whether Wittgenstein's writings were intended to (or do) express positive theses and claims, or whether they were intended to provide philosophical therapy by helping us to see the
\end{abstract}


hopelessness of arriving at any satisfactory philosophical theories. ${ }^{7}$ This debate stems from the next-to-last section of Wittgenstein's early Tractatus LogicoPhilosophicus. After having apparently articulated a theory of language, Wittgenstein writes: 'My propositions serve as elucidations in the following way: anyone who understands me eventually recognizes them as nonsensical, when he has used them - as steps - to climb up beyond them. (He must, so to speak, throw away the ladder after he has climbed up it.) He must transcend these propositions, and then he will see the world aright.. ${ }^{8}$ On the view that Wittgenstein intended his book to put forward a theory about how language works, this passage is in essence a reminder that the theory is intended to get us to grasp something that cannot be directly said (because saying it would require an Archimedean point outside of language from which to see the whole picture - more below), and that therefore the preceding text has been partially defective if evaluated by its own standards. On the view that the book was intended primarily as therapy, this passage is the crux of the entire text, since it (hopefully) leads to the recognition that what had appeared to be a compelling theory of language (one that deftly revealed the inner contradictions of the other contending theories and showed why any alternative would be grounded in absurdity) is itself absurd, since it has gained its ostensible victory only by violating its own rules (by saying something that cannot sensibly be said), thereby helping us see the futility of theorizing about language at that would-be-universal level of abstraction.

These two positions both have eloquent and well-respected partisans, and efforts to chart a middle path between them have come under strong criticism. ${ }^{9}$ I wish to state plainly that I have nothing to add to this debate, and that I have no pretensions to resolving it. In this article, I will discuss Wittgenstein's work as if it were intended to convey a theory (or two) 
about language, for two reasons: first, that is how the work presents itself to me, even after seriously considering the arguments of the therapeutic school; second, the focus of this article is the literature on the normative/political significance of Wittgenstein's work, and most of that literature (though not all, as I discuss below) takes the theory approach to interpretation. However, one main contention of this article is that the theoretical and therapeutic schools ought to converge in their assessments of the normative and political significance of Wittgenstein's writings, so that while my approach is theoretical, my conclusions are also therapeutic. On the view argued below, both schools ought to conclude that Wittgenstein's work has no normative or political consequences whatsoever.

A second main contention of this article is that coming to a correct understanding about the normative and political implications of Wittgenstein's philosophy will shed some much-needed light on the problem of value pluralism. Since the publication of Isaiah Berlin’s celebrated essay ‘Two Concepts of Liberty’ in 1958, political theorists and philosophers have been grappling with the idea that moral values can irreconcilably conflict with one another, not only between competing value systems, but also within the conscience of an individual. ${ }^{10}$ This idea has led to an enormous volume of writing trying to assess and extend Berlin's insight. ${ }^{11}$ Two great questions have motivated this research. (1) Are values plural in the way that Berlin suggests? (2) Does value plurality lead to, reveal, or require as a response some substantive normative duty (for example, Berlin's suggestion that plurality reveals an obligation to respect negative liberty), or does it lead to moral relativism (a situation in which we lack a principled reason to judge any value or system of values as morally better or worse than any other)? 
There are two general strategies for trying to answer the first of these questions, as to whether values can be plural. Realist pluralists argue that values are real, humanindependent (at least to some degree) facts about the universe, and that there are many such values that can come into irreconcilable conflict with each other because they do not have any intrinsic rank order. Isaiah Berlin, John Gray and William Galston all take this position. ${ }^{12}$ Irrealist pluralists argue that values are not real things in the humanindependent universe - that they are, for example, contingent and context-relative cultural beliefs or habits - but that they can nonetheless come into (practically) irresolvable conflict with each other. These conflicts, which amount to an inability to rank the various values, arise precisely from their contingency and relativity - there is no objective ranking criterion available. Irrealism of this kind is famously associated with Nietzsche ,13 and Richard Rorty adopts a similar position. 14

There is an extensive literature on realist pluralism, with one side arguing that the fact of value plurality itself demonstrates, reveals, or leads to some kind of normative duty (to toleration, to encouraging plurality of lifestyles, to peaceful coexistence), and with the other side arguing that value plurality is morally neutral, neither endorsing nor undermining any substantive value orientation. ${ }^{15}$ In this article I will examine irrealist pluralism, which is often quickly passed by in the current literature.

Many readers of Wittgenstein interpret him as giving an explanation of meaning and knowledge that is very close to irrealist pluralism. On this 'conventionalist' reading, meaning and knowledge are both cultural constructs, relative to a particular 'form of life'. Because there is no Archimedean point, no position from which we can evaluate how well our ideas map onto the real world that we presume to exist independent of 
our concepts, we are permanently incapable of ascertaining the adequacy or ultimate ‘truth' of our descriptions and claims. Rather, whatever evaluations we make of meaning or meaninglessness, of veracity or falsehood, of utility or uselessness, are made from within our cultural context. Extending this analysis to include normative as well as descriptive language, we can argue that Wittgenstein's philosophy (perhaps as opposed to his personal beliefs) suggests that people from different forms of life may have radically different moral beliefs, and that they may lack a common vocabulary with which to argue and attempt to persuade each other. On this reading, moral values can indeed be plural, precisely because they float free of any objective, universal standard or criterion against which to evaluate and thus rank them. If that is truly the case, political cooperation appears to become much more difficult, since we have no reasonable expectation that all the citizens of a polity will (or can be brought to) endorse the same values or institutions. That kind of plurality among citizens threatens either chaos (the inability to achieve stable social cooperation) or oppression (the achievement of cooperation only by the suppression of principled dissent).

In essence, while pursuing other questions, the conventionalist interpreters of Wittgenstein have put forward a variety of answers to the two questions driving the pluralism literature. On the one hand, they have asserted that values can be and are plural, because of their being irreal. (And in the process they have articulated a coherent defense of that kind of moral irrealism.) On the other hand, they have put forward a variety of answers to the question of what normative implications irrealist pluralism might entail. In this article, I explicate and examine the conventionalist reading of Wittgenstein as a theory of moral irrealism, and I respond to criticisms of this 
approach. I then examine the various normative interpretations of this reading, and argue that the various efforts to attribute a positive normative content to the theory are mistaken. Rather, I argue, the true implication is the one identified by a small group of theorists who see Wittgenstein as calling us to greater attention to our actual moral practices, including their internal conflicts and instabilities, rather than as calling us to endorse any particular beliefs. If this interpretation is correct, it suggests an unusual answer to the second question motivating the value pluralists, by claiming that value pluralism has no normative consequences at all. A conventionalist reading of Wittgenstein

Just as there is ongoing controversy about how to understand Wittgenstein's writings overall, there is also controversy regarding innumerable concrete issues of interpretation. One of the most important of these controversies concerns how to understand the relationship between Wittgenstein’s early Tractatus Logico-Philosophicus and his later work, primarily the posthumously collected and published books Philosophical Investigations and On Certainty. The main line of dispute is whether the theories laid out in the earlier and later works are profoundly similar or profoundly different. Here, too, I make no claim to resolving this controversy or even to adding anything to it. In this article, I will present the two theories as being significantly different, for two reasons: first, the theories present themselves that way to me, though I acknowledge that there are many similarities between the earlier and the later work; second, because emphasizing the differences between the theories makes it easier to explicate the later theory quickly for non-specialists.

In his early Tractatus Logico-Philosophicus, Wittgenstein starts from the premise that, for language to be meaningful, it must have definite reference - it must unproblematically refer to identifiable features of the world of experience. In other words, for meaning to be clear, it must 
somehow be possible to match up word and world. ${ }^{16}$ For this to be possible, Wittgenstein reasoned, the world and the language that depicts it must share essentially the same structure both must be made up of discrete units capable of existing in a large but finite and knowable number of relationships to each other. For a proposition to have meaning, it would have to assert a possible relationship among actually existing kinds of objects, what Wittgenstein calls a state of affairs. For a proposition to be true, it would have to describe a state of affairs that actually exists. In essence, Wittgenstein is arguing that we understand the meaning of a sentence by understanding the profoundly similar grammar of the world .17

However, a central focus of the Tractatus is the contention that this connection between word and world is a transcendental premise. Because we cannot separate ourselves from our concepts to evaluate how well they match up to the world, it is impossible to evaluate or prove whether our words accurately reflect the real. Wittgenstein's argument in the Tractatus is that a close correspondence between word and world is a condition of possibility for language to function at all, but is not and cannot be a hypothesis, or even a meaningful proposition (since it purports to make a claim that it is logically impossible to investigate or evaluate).

Much of his later work is dedicated to undermining these early arguments. Take first the idea that the world must be made up of discrete things - atomic simples - in roughly the way that a proposition is made up of discrete subjects and qualifiers held together by a predicate. Wittgenstein's argument against atomism in the Philosophical Investigations is straightforward: in many cases there is no way to identify what the absolutely simple elements of the world are. Wittgenstein writes:

But what are the simple constituent parts of which reality is composed? - What are the simple constituent parts of a chair? - The bits of wood of which it is made? Or the molecules, or 
the atoms? -'Simple' means: not composite. And here the point is: in what sense 'composite'? It makes no sense at all to speak absolutely of the 'simple parts of a chair.' ${ }^{18}$ Wittgenstein's point is not that we have simply not yet been able to identify the most basic, notfurther-fissionable elements of reality. Rather, his point is that the level of basic-ness in question is always a matter of context. This suggests that simplicity is a result of linguistic practice, rather than the basis of it. On this reading, there simply are not objectively identifiable atomic simples. 19

Wittgenstein's argument against ourbeing able to identify the 'grammar' of the world- the rules governing what relationships among things are possible - is more complex. On my reading, it comprises three related points. In the first, Wittgenstein argues that we neither have nor need comprehensive rules for using language. He writes:

I say 'There is a chair'. What if I go up to it, meaning to fetch it, and it suddenly disappears from sight? ... Have you rules ready for such cases - rules saying whether one may use the word 'chair' to include this kind of thing? But do we miss them when we use the word 'chair'; and are we to say that we do not really attach any meaning to this word, because we are not equipped with rules for every possible application of it? ${ }^{20}$ Here, Wittgenstein is pointing out that we do not have a comprehensive set of rules about possible states of affairs in the world, a condition of meaningfulness in his earlier theory. Rather, he argues, we articulate relatively narrow rules to avoid specific confusions: 'One might say: an explanation serves to remove or to avert a misunderstanding - one, that is, that would occur but for the explanation; not every one that I can imagine. ${ }^{21}$

The second part of Wittgenstein's argument against our being able to fully specify what he calls 'logical form, ${ }^{22}$ is aimed against the idea in the Tractatus that language has only one 
purpose: to express true or false propositions about the world. In the Investigations he proposes the terminology of family resemblance to express the idea that language is made up of a variety of activities that are only loosely related to one another:

Instead of producing something common to all that we call language, I am saying that these phenomena have no one thing in common which makes us use the same word for all, - but that they are related to one another in many different ways. And it is because of this relationship, or these relationships, that we call them all 'language. ${ }^{23}$

The third part of Wittgenstein's argument against the transparency of logical form is the contention that logic - that is, statements about what statements are possible or meaningful depicts not the world but only our grammar, our ways of speaking. He writes:

What looks as if it had to exist, is part of the language. It is a paradigm in our languagegame; something with which comparison is made. And this may be an important observation; but it is none the less an observation concerning our language-game - our method of representation. $^{24}$

More sharply, he maintains: ‘Grammar does not tell us how language must be constructed in order to fulfill its purpose, in order to have such-and-such an effect on human beings. It only describes and in no way explains the use of signs. ${ }^{25}$

Once Wittgenstein has undermined the claims that we can identify the atomic elements of the world of experience and that we can identify the comprehensive rules of logical/grammatical form, he has effectively undone the Tractatus. Without those two supporting hypotheses, the main contention of the Tractatus - that language and the world must share a fundamental structure for language to have sense - is not so much wrong as hopelessly vague. It remains intuitively persuasive that there must be some connection, but, with no hope of identifying 
either the basic elements or the necessary rules of combination, there seems no possibility of explicating or testing that commonality even as a transcendental premise.

Having abandoned the Tractarian theory, Wittgenstein now has to come up with an alternative. One popular interpretation of his alternative is that it is conventionalist - that is, that it grounds meaning in the contingent habits of particular communities. On this view, he begins by arguing that words have meaning not because of their relationships to things or states of affairs but because of their relationships to linguistic practice: 'For a large class of cases though not for all - in which we employ the word "meaning" it can be defined thus: the meaning of a word is its use in the language. ${ }^{26}$ Similarly: 'Now what do the words of this language signify? - What is supposed to show what they signify, if not the kind of use they have? ${ }^{27}$

However, it is not immediately obvious that this explanation is adequate. One pressing problem is that it is not clear how to resolve disputes over meaning. The temptation is to try to provide a rule - a definitive interpretation of the meaning of my utterance. But what will show what the rule means? Another rule? And what will show what that rule means? ‘[A]ny interpretation still hangs in the air along with what it interprets, and cannot give it any support. Interpretations by themselves do not determine meaning. ${ }^{28}$ Having removed the stable stopping-points of atomic simples or necessary rules of logic and grammar, Wittgenstein seems to have opened up an infinite regress of interpretation. As he puts it: 'This was our paradox: no course of action could be determined by a rule, because every course of action can be made out to accord with the rule. ${ }^{, 29}$ His answer to this apparent problem is to ground meaning in shared practice: 
Let me ask this: what has the expression of a rule - say a sign-post - got to do with my actions? What sort of connexion is there here? Well, perhaps this one: I have been trained to react to this sign in a particular way, and now I do so react to it.... [A] person goes by a sign-post only in so far as there exists a regular use of sign-posts, a custom. 30

This theory of language and meaning points to a theory of justification that is broadly contextualist. ${ }^{31}$ When I want to justify a knowledge-claim to you I offer reasons rooted in our shared form of life. For many situations this will probably be adequate. But what happens when I try to dig deeper - for example, when I try to assess the form of life itself? Wittgenstein argues that justification eventually comes to a practical end: “'How am I to obey a rule?”- if this is not a question about causes, then it is about the justification for my following the rule in the way that I do. If I have exhausted the justifications I have reached bedrock, and my spade is turned. Then I am inclined to say: “This is simply what I do.”,32

In On Certainty Wittgenstein deepens this argument by maintaining that all justification necessarily takes place within a system of beliefs and practices (i.e. a form of life). Such a system must, if justification is to come to an end (that is, succeed), rest on some ultimate grounds - some beliefs or practices that are the final criteria of truth and falsity. Yet those final criteria cannot themselves be either true or false, since there is nothing against which to evaluate them. ${ }^{33}$ Our world picture may change over time, ${ }^{34}$ but its fundaments at any one time are not likely to be open to evaluation. Similarly, we come by our world picture not piece by piece, and not through satisfying ourselves of its truth, but rather all at once, as the world. 'When we first begin to believe anything, what we believe is not a single proposition, it is a whole system of propositions. (Light dawns gradually over the whole.). ${ }^{35}$ Wittgenstein and moral epistemology 
In the Tractatus Wittgenstein argued that words referring to morality, religious concepts (God, soul, etc.), aesthetics and logic were all strictly meaningless. Since they do not refer to any tangible features of the world, they have no meaning at all. He wrote: 'It is clear that ethics cannot be put into words. Ethics is transcendental. ${ }^{36}$ To avoid speaking nonsense, and perhaps to avoid debasing the incomparably valuable by merely babbling, Wittgenstein suggests that we acknowledge the meaningless of our normative concepts: 'What we cannot speak about we must pass over in silence.' 37

Wittgenstein took essentially the same line in his middle-period 'Lecture on Ethics'. He continues to think that normative language has no meaning, but he seems to have a new appreciation of how very difficult it would be to stop using it. He writes:

I see now that these nonsensical expressions were not nonsensical because I had not yet found the correct expressions, but that their nonsensicality was their very essence. For all I wanted to do with them was just to go beyond the world and that is to say beyond significant language. My whole tendency and I believe the tendency of all men who ever tried to write or talk Ethics or Religion was to run against the boundaries of language. This running against the walls of our cage is perfectly, absolutely hopeless. Ethics so far as it springs from the desire to say something about the ultimate meaning of life, the absolute good, the absolute valuable, can be no science. What it says does not add to our knowledge in any sense. But it is a document of a tendency in the human mind which I personally cannot help respecting deeply and I would not for my life ridicule it. ${ }^{38}$

But the theory of meaning in the Investigations leads to a different conclusion. In both the Tractatus and the 'Lecture', Wittgenstein is still working from the idea that meaning must be referential - that the words get their meaning by referring to some identifiable thing. But in the 
Investigations he abandons that view in favor of the idea that words get their meaning from how they are used - from their place in a form of life. On that view, words like 'God', 'right', 'wrong' and so on have as much meaning as words like 'hammer', 'squirrel' and 'molecule', and for the same reasons.

The theory of justification developed in On Certainty also extends to normative concepts. Propositions like 'God is good', or 'Murder is wrong', can be true or false in exactly the same way as propositions like 'The squirrel is asleep on the roof'and 'The glass is filled with molecules of water'. What makes a proposition like 'Murder is wrong' meaningful to you and me is that it plays a part in our shared form of life. What makes it true or false similarly depends on our form of life. For example, for some people, the existence of the world is itself conclusive evidence for the existence of a creator god, while for people in a different form of life, it is not. Wittgenstein's theory does not (and cannot) tell us which view to take on this question, though it does help explain why people can disagree so drastically.

On this reading, Wittgenstein’s epistemology naturally leads to a moral epistemology in which irrealist value pluralism is possible and coherent. Moral language gets its meaning, and moral claims their truth or falsity, by reference to one's form of life. If a form of life is internally complex or fragmented - if, for example, it contains conflicting religious traditions then it may well contain values that conflict. To the extent that an individual participates in multiple such traditions, she or he may personally hold values that, upon reflection, are both incompatible and incommensurable with one another. For the same reasons, it is possible that different groups of human beings will have different forms of life. Groups may disagree not only on the content of moral values, but perhaps even on the grammar of expressing them. One of the main implications of Wittgenstein's view is that there are no features that all forms of 
life must contain. If we find ourselves confronted with apparent value plurality, Wittgenstein's theory suggests that the only possible basis of eventual agreement is if we find that we share enough of a form of life to ground a common meaning or understanding. There is no reason to believe that such agreement must always be available, and persistent disagreement is itself evidence that we do not share enough of a form of life to agree on these questions. To the extent that our value terms have conflicting meanings - or that our value systems rank shared meanings in different ways - value will indeed be plural among us. 39

Criticisms of the conventionalist reading

The conventionalist reading of Wittgenstein's later work that I have just summarized has been subject to a number of criticisms. Perhaps the most general is the claim that his writings were not meant to convey positive theories at all, and that therefore every interpretation that puts forward claims about how language works must be wrong.${ }^{40}$ As I noted above, although I believe there is a lot of merit to this 'therapeutic' reading of Wittgenstein, I am not ultimately convinced by it. Thus, on my view, Wittgenstein's writings were intended to convey a positive theory of some kind, and it is reasonable to attempt to decipher what we think that theory is.

A second criticism of the conventionalist reading is that it is too strong, and that it violates the spirit of Wittgenstein's philosophy by pretending to have exactly the Archimedean perspective on how language works that Wittgenstein ceaselessly demonstrated we could never have. A strong advocate of this line of criticism, especially with regard to Wittgenstein’s significance for politics, is Alice Crary. In her essay ‘Wittgenstein’s Philosophy in Relation to Political Thought', Crary argues that the conventionalist reading violates the very heart of Wittgenstein's philosophy. ${ }^{41}$ She writes: '[Wittgenstein] is 
attacking the idea of a perspective on language as if from outside from which we can discern either that there are features of reality which underlie our practices and determine their correctness or that there are no such features and that something else - such as our linguistic conventions - determines what counts as correct. ${ }^{, 42}$ She continues: 'Wittgenstein hopes to expose as confused the idea that meanings might somehow be "fixed" (whether independently of use or otherwise). There is, he wants us to grasp, no such thing as a metaphysical vantage point which, if we managed to occupy it, would disclose to us that meanings were "fixed" in one way or another ... '43

Crary is clearly right, though I believe the consequences are not what she expects. A strong conventionalist reading, like the one I summarized above, which says 'meaning is determined by the way we use words', clearly does violate the spirit of Wittgenstein's whole philosophical enterprise. From the Tractatus to the Investigations, Wittgenstein tried to show us that we simply cannot get the kind of perspective on language necessary to substantiate claims like this.

But if the conventionalist reading takes the weaker position of saying 'the way we use words is the only evidence available as to their meaning', then Crary's objection gets no purchase. In other words, Crary is exactly right that the stronger version of conventionalism rests on a claim that is logically impossible to prove - that meaning floats free of the real. To prove that point would require us to have a vantage point separate from both language and the real, from which we could assess the (lack of) connection between them, and that is precisely the vantage point that Wittgenstein has been showing us we cannot have. But the weaker form of conventionalism requires no such impossible vantage point. Rather, it is the observation that we are unable to tell whether meaning is determined by 
convention, by connection to the real, or by other yet more bizarre influences. As Wittgenstein deftly points out, precisely because of our lack of a metaphysical vantage point, we have only the way words are used as evidence of their meaning. Remember: 'Now what do the words of this language signify? - What is supposed to shew what they signify, if not the kind of use they have?,44

This weak conventionalist position requires one more step: if we now want to investigate the meanings of words - or, as I suggested above, the truth or falsity of propositions - we have no choice but to act as if strong conventionalism were true. Because the use of words is our only evidence, and because we cannot suspend judgment because of the possible existence of other influences for which we could in principle never obtain evidence, the only possible way of examining meaning and knowledge, given Wittgenstein's insights, is to act like strong conventionalists. We should, of course, remember that strong conventionalism is too strong, but that will have relatively little effect on our day-to-day work. If Wittgenstein's position in the Tractatus was a true transcendentalism, in which we should view language as an accurate reflection of the real because that is the only logically possible explanation, his later position is a kind offaute de mieux conventionalism, in which we must treat meaning as determined by use only because we are unable to justify any other way of proceeding.

A third and final kind of criticism of the conventionalist reading will help us segue to the question of the political significance of Wittgenstein's work. A number of authors, among them Gaile Pohlhaus and John R. Wright, ${ }^{45}$ as well as Paul Livingston, ${ }^{46}$ have argued that conventionalist readings are inevitably conservative. Livingston ties the conventionalist reading to political conservatism, on the grounds that the emphasis on traditions and habits as the basis of meaning leads to a reification of the existing social and intellectual order. For example, 
Livingston writes: 'Within the context of this usual way of viewing Wittgenstein's critical intentions, his appeal to practice can seem to have an essentially conservative flavor. On the usual interpretation, the purpose of Wittgenstein's treatment of meaning as use is to remind us that a word only has significance insofar as it functions within a well-defined and established ordinary practice ... ${ }^{47}$ On Livingston's view, we should instead understand Wittgenstein to be proposing a method of investigating meaning rather than a positive explanation of language. This approach would allow us to employ the quasi-conventionalism that Livingston agrees is found in Wittgenstein's work, while at the same time allowing us to avoid the reification that a full-blooded conventionalism seems to him to threaten. He writes:

But we can nevertheless take away from [Wittgenstein] the possibility of a self-directed critical practice of reflection. This practice works to elucidate the meanings of words by reminding us of the ways in which they are typically used, and by demonstrating the ordinary tacit conventions and norms that govern them. But purged of the assumption that this elucidation must result in the demonstration of a stable totality of rules, this practice becomes as multiplicitous ... [as] language itself. ${ }^{48}$

Pohlhaus and Wright have a subtler definition of conservatism, seeing the conventionalist reading as being 'philosophically' conservative. Their claim is that conventionalism, like dogmatic philosophy, seeks to end debates, especially about fundamental issues, rather than seeking to continue them. Thus they write:

At the very least, ideals that could pose ... radical challenges seem too readily dismissed by such views as childish dreams that fail to recognize 'the current condition of human circumstances.' This danger is an inherent part of what we will call 'philosophical conserva- 
tism': those philosophical positions that limit possible meaning within the constraints of existent practices or a particular understanding of human nature. ${ }^{49}$

On their reading, Wittgenstein sought to help us to take radical challenges seriously, by showing us how to listen to and understand the claims of the skeptic or the minority viewpoint. Hence: 'These claims and appeals situate the possibility of self-knowledgewithin a shared form of life but also raise questions as to who has authority to make claims about what "we" say. It is these latter questions that the conventionalist reader fails to address. ${ }^{, 50}$

Not surprisingly, Livingston and Pohlhaus and Wright believe that their alternative readings of Wittgenstein reveal particular political consequences in his work. Livingston argues that seeing conventionalism as a method rather than a fact about language allows us and even encourages us to engage in criticism of reified concepts and institutions within our society. He writes:

Wittgenstein's critical reflection on rules offers a position from which it becomes possible both to question the assumptions of regularity and fixity that underlie typical practices of calculation and legislation, and to criticize these practices themselves on that basis. When, in particular, large sectors of social practice and prevailing institutions become governed by deeply held assumptions of regularity and uniformity, such a critical reflection on the sources of these assumptions becomes particularly important. ${ }^{51}$

Pohlhaus and Wright's argument rests on the idea that if the skeptic or the critic is also part of the 'we' that defines what 'we' say, then refusing to listen or pretending that their claims are nonsense is not only unjust to them, but also undermines our own identities and our understanding of our own ideas. (As, for example, a scientist who refuses to examine empirical data that undermines his favorite theory is himself undermining it by taking it 
out of the realm of science (the empirically verifiable) and moving it to the realm of dogma.) We can only be us if we listen to everyone who is part of us, and that entails ensuring that they are able to give voice to their views. Thus: '[O]ur desire for selfknowledge implies a commitment to a liberal society of a particular shape ... that is, one in which each member is free and equal in contributing to its structure and governance ... [and in which] each member can achieve self-knowledge through intelligibly articulating her claims to the group., 52

I believe that Livingston and Pohlhaus and Wright are mistaken in their claims that Wittgenstein's philosophy encourages or requires us either to engage in criticism of reification or to create social equality as a condition of having meaningful identities and beliefs. However, I cannot fully explain my arguments until we have considered more whole-hearted conventionalists below. This is because, despite their effort to distance themselves from conventionalism, both Livingston and Pohlhaus and Wright in fact embrace conventionalist readings of Wittgenstein, though with reservations that they believe will save them from sin. Livingston confessed his conventionalism above, when I quoted him as saying that we should embrace a conventionalist reading, but as a practice rather than as an explanation. Pohlhaus and Wright stake their claim and their reservations here: 'For Wittgenstein, mutual intelligibility is delimited by our human form of life, but what counts as such a life is precisely what is in question ...' 53 So, onto conventionalism. The consequences of conventionalism As has become clear, most interpreters of the normative consequences of Wittgenstein's philosophy do read him as putting forward some version of conventionalism. Where they differ is over the consequences of that conventionalism. The literature can be organized into 
three general lines of argument, which I call normative, relativist and neutral. The normative parts of the literature argue that Wittgenstein's philosophy of language and knowledge leads to some set of positive normative obligations. The relativist parts of the literature argue that moral relativism is the inevitable consequence of Wittgenstein's conventionalism, and some of these interpreters further claim that embracing relativism will make normative deliberation, discussion and decision-making impossible. Finally, the neutral part of the literature argues that conventionalism leads neither to positive normative obligations nor to nihilism, but rather leaves everything as it already is.

Normative, part I: Wittgenstein as liberal or democrat Contrary to Livingston's claim that the conservative reading of Wittgenstein is ubiquitous, ${ }^{54} \mathrm{a}$ number of interpreters read Wittgenstein as supporting some form of liberalism or democracy. These perspectives seem to emerge from two ideas: (1) that a plurality of values and interests appears to be inevitable, given Wittgenstein's epistemology; (2) that this plurality gives rise to a normative obligation to toleration.

One of the more extreme interpretations of Wittgenstein is given by Aryeh Botwinick, who reads Wittgenstein's epistemology as profoundly skeptical, and as implicitly supporting a form of radical democracy. Botwinick's main argument is simple and straightforward: 'Since no one individual's or group's claims to knowledge or authority can be better intellectually grounded (from an absolutist philosophical perspective) than any other, an equality between citizens' power positions should be preserved throughout the life span of a particular society.' 55

A more nuanced position is articulated by Richard Eldridge, who sees Wittgenstein as committed to a tolerant substantive liberalism: 'What follows, then, from the condition of the human person that is enacted in Philosophical Investigations is, I think, a kind of substantive or 
weak perfectionist liberalism.... But this framework will express a commitment to a substantive good - personal autonomy; it will not of itself neutrally settle conflicts about the scope and value of this good. ${ }^{56}$

Lawrence Hinman advocates a similar reading of the implications of Wittgenstein's epistemology: 'There is no absolute form of life in relation to which the validity of particular forms of life may be determined, yet the task which confronts us is the creation of a finite form of life in which contemporary competing forms of life can find their true expression.' 57

Finally, Linda Zerilli argues that Wittgenstein’s commitment to grappling with the strange and difficult ways of other forms of life suggests an implicit commitment to toleration:

Wittgenstein’s legacy suggests that any decision about which perspective shall stand will not be based on annihilating the other point of view. We can hear competing perspectives, and we can still make choices. Our lives with others do not have to amount to a zero-sum game; our choices do not have to reduce the other to unintelligibility. We can live by values other than the principle of agreement with oneself. ${ }^{58}$ These are attractive readings, and clearly they depict possible outcomes in a world in which Wittgenstein's descriptions of language, knowledge, and justification are recognized as true. But are they necessary outcomes? Is it the case that someone who reads Wittgenstein must, on pain of self-contradiction, adopt a liberal or tolerant approach to difference and political conflict? It seems obvious that the answer is no. If values really are conventional, and therefore relative to particular forms of life, there is no reason to think that all forms of life will hold liberal or tolerant values. On the one hand, there is no reason to think that all forms of life will contain these views as positive value commitments - it seems perfectly plausible that there will be forms of life that reject liberal and tolerant views, and of course we know from experience 
that some forms of life do just that. On the other hand, there is no reason to think that all forms of life will respond to the fact of pluralism by adopting an accommodationist or tolerant attitude. Whatever response people make will inevitably be grounded in their form of life, and there is no reason to think that all forms of life will respond to value conflict in the same way (or even, as discussed below, that all individuals within a single form of life will do so). If we are going to take the contextual relativity of values seriously, we will have to recognize that there is no reason to believe that such value systems must overlap, though of course they may do so as an empirical matter.

Normative, part II: Wittgenstein as conservative A number of thinkers have indeed understood Wittgenstein to be implicitly committed to a Burkean or Oakeshottian conservative position, in which our form of life is best not because of its intrinsic qualities, but merely because it is ours. The starting point for most of these analyses is Wittgenstein's insistence that meaning and knowledge are rooted in a form of life, and thus in a tradition whose acceptance and perpetuation appear to be essential to continued social existence. If meaning depends on the stability of a form of life, then it appears that Wittgenstein may place a high premium on preserving that form of life. J. C. Nyiri puts the point like this: The following of a rule is a custom, an institution, embedded in the agreements, in the correspondences of behaviour within society. The question concerning the interpretation of any rule can be raised - though it need not be - and it should be answered by referring to agreements in behaviour. Rule-following is, in the last analysis, blind: it cannot be explained or justified.... 59

Nyiri goes on: 'The decisive point however is that ... we cannot entertain a liberal attitude as regards irregularities in our own society. For it is through compelling uniformities that the life 
of a society becomes ordered, such uniformities determine the boundaries of a society, that is, only through such uniformities does the society as such become constituted. ${ }^{, 60}$

Here, too, there is clearly some plausibility to this reading. But, as a number of commentators $^{61}$ (largely overlooked by Livingston and by Pohlhaus and Wright) have noted, the conservative interpretation rests on two contestable and ultimately implausible assumptions. First, it assumes that forms of life are internally consistent and homogeneous, so that every member will always respond to the same problem in the same way. 62 Second, it assumes that forms of life are hermetically sealed off from one another, such that there can be no meaningful cross-cultural influence or exchange. Not only are both assumptions implausible as factual claims, they are both flatly contradicted by Wittgenstein’s writing.

The theory of the Philosophical Investigations - in particular the arguments about family resemblance and following a rule - seems to suggest that a form of life is a loose assemblage of language-games and social practices that are related in a variety of ways. It seems not only possible but likely that there will be internal contradictions within a form of life, languagegames whose implications contradict other language-games, institutions that conflict with institutions, and so on. Even if it were true that there is a conservative tendency inherent in rooting meaning and knowledge in language-games and social practices, it seems that the very same process is likely to give rise to conflicts and competing interpretations within a single form of life. As Richard Flathman writes: ‘[M]uch in Wittgenstein’s later writings suggests that enlargements of the commonalities that enable mutual understanding and facilitate interaction go hand in hand with, in a certain sense bring about, obscurity and a kind of opacity.' 63

Similarly, the porosity and complexity of a form of life suggest that it will be likely to have multiple lines of connection and interaction with other forms of life, which will also be 
internally complex and fragmented. Catholicism is part of the forms of life of both Mexico and the United States, and though it plays very different roles in the two countries, and despite the fact that the Catholic community is internally fragmented and conflictual, this commonality of faith clearly creates lines of communication across the national border. Just as forms of life are not internally monolithic, they are not externally sealed.

Thus, those who see the conventionalist reading of Wittgenstein leading to conservatism both those like Nyiri who are happy with that outcome, and those like Livingston and like Pohlhaus and Wright who are unhappy with it- are using far too simple a conception of forms of life. When, following Wittgenstein's lead, we see forms of life as both complex and overlapping, we can see that conventionalism does not necessarily lead to conservatism. Could people who read Wittgenstein as a conventionalist still be conservatives? Of course: witness Nyiri. But there is no reason that they must be, and there are plenty of resources available within any form of life to arrive at a different outcome.

Wittgenstein as relativist

As with the reading of Wittgenstein as a conservative, so among readers of him as a relativist there are apparently those who celebrate that implication and those who condemn it. The person most associated with the idea that Wittgenstein's theory leads to a beneficial relativism is Richard Rorty, ${ }^{64}$ which is ironic since that is not in fact Rorty's view. Instead, Rorty reads Wittgenstein as a post-Kantian, or perhaps as a retro-Pyrrhonian, whose contribution is to help us grasp that we cannot know whether our words or our ideas are true in the deep sense of being necessary or connected to thought-independent reality. Given that position, debates about moral truth (like other kinds of truth) simply become pointless - they are irresolvable, and thus neither the dogmatist nor the skeptic can win. Rather than continuing a fruitless debate, Rorty 
suggests that we change the topic, and talk about something else (like social policy). Implicit in that position is the assumption that we will continue on with whatever concrete words and ideas we happen to have already. ${ }^{65}$ On this reading, Rorty's view is much closer to that of the 'neutral' readers of Wittgenstein, whose general position, I argue below, is largely correct.

Not surprisingly, most of those who really do read Wittgenstein as a relativist tend to conclude that he must therefore be a nihilist. They argue that, since a commitment to one's own form of life appears to be a condition of making meaning, and since the same must be true of those in other forms of life, there is apparently no way to evaluate forms of life from the outside: 'Remember that Wittgenstein said that "forms of life” were a kind of ultimate data beyond the reach of questioning. My form of life, right or wrong.' 66 Instead, we are condemned to saying that every form of life is correct in its own terms, and that no meaningful criticism of a form of life can be made from outside that form of life itself. As Ernest Gellner puts the point: 'When, however, this leveling out, this relativism, is articulated in terms of entire cultures, it then places a cognitively cumulative culture on the very same level as stagnant and self-revering ones.' 67

The charge of relativism, and thus of nihilism, is the oldest and most persistent criticism of conventionalist theories. The criticism that contextual or relativistic theories of morality lead to nihilism is really two related but distinct claims. The first is the idea that acknowledging the relativity of one's beliefs makes judgment logically impossible or incoherent. On this view, if I accept that my normative beliefs are the product of my culture, and if I accept that other, different beliefs are the products of other, different cultures, then I have no logical basis for claiming that my beliefs are either superior (or inferior) to 
anyone else's. The lack of a universal standard of evaluation makes ordinal judgment impossible. This is the basis of Gellner's criticism of Wittgenstein above. The second aspect of the charge that contextual theories of morality lead to nihilism is the idea that recognizing the relativity of our moral beliefs will slowly sap our willingness to act in accordance with them. Once we lose the idea that certain moral duties are universal obligations, and instead come to believe that they are merely contingent and contextrelative ways of life, some combination of selfishness, ignorance and apathy will lead us either into brutality or into a numb mediocrity. This is the kind of nihilism of which Nietzsche was so very afraid, though he thought that we were much more likely to end up in mediocrity than in brutality (which would have at least shown some spirit). ${ }^{68}$

The Wittgensteinian response to the first charge - that acknowledging the relativity of values will make normative judgment logically impossible - is roughly the same as the response to profound skepticism. On the one hand, the recognition that our beliefs are relative does not do away with the human and social needs that those beliefs addressed. On the other hand, forms of life are never logically consistent systems but are rather sedimentary accretions of habits, practices, games, mistakes, misunderstandings, and so on. Just as recognizing our inability to know whether our perceptions are accurate or our knowledge true does not make it either necessary or possible for us to do away with them, so, too, recognizing that our beliefs are contingent does not make it necessary or possible for us to discard them. I cannot pursue what I recognize as a decent life without having some beliefs about the subjects of morality, and I am not free to jettison or replace wholesale my existing conception of a decent human life. Practically, I have no choice but to proceed with my existing normative beliefs, whatever they are, and 
no matter how internally fragmented or contradictory they may turn out to be on closer inspection. This situation does not require me to moderate my beliefs or to treat others with tolerance or consideration, unless the substance of my beliefs requires such things. Doing so in contravention of my original beliefs would be adopting new beliefs, not continuing on with the old ones. My new acknowledgement of the relativity of my beliefs may inspire me to reflect on their content, but it may not. What it will not and cannot do is to cast me loose from all beliefs. And since judgment is comparing my beliefs against my experience, if I have beliefs I will continue to make judgments, including moral judgments.

The second charge of nihilism - that acknowledging the contingency of our values will sap our will to obey them - is harder to respond to. In essence, it is a claim about human nature - that human beings are not capable of exercising self-control, or of motivating themselves to take actions against their inclinations (towards selfishness, sloth, etc.) without believing in the existence of moral obligations that transcend mere habit, common sense, tradition, and so on. This is a question of whether we agree with Nietzsche, who believed that human beings could and should overcome the idea of there being absolute moral standards, or with Plato, who believed that genuine knowledge of the good was both possible and also essential to successful human life ${ }^{69}$ The Wittgensteinian position, as I have been arguing, does not contain any particular view of human nature, yet the fact that Wittgenstein theorized as he did suggests that he believed that acknowledging the conventionalism (whether weak or strong) of our beliefs was not only possible, but desirable. To that extent, at least, it seems that Wittgenstein himself did not believe that his theory would have any disastrous consequences.

No normative consequences: reminders for a particular purpose 
A number of recent commentators have suggested that, while Wittgenstein does have a normative project in his later works, it is structural rather than substantive. Rather than telling us what kind of ethical or political life to lead, Wittgenstein is trying to 'assemble reminders' for us about what it means to have a normative life at all. From this perspective, Wittgenstein is calling upon us to be awake to the normative dimensions of our forms of life, to pay attention to the language-games that we actually play, to refuse to be unconsciously captured by any particular picture of how things 'must be'. 70 Wittgenstein, as it were, is calling upon us to actually live our ethical and political lives, whatever their content, and to do so with our eyes open. As James Edwards writes: ‘[Wittgenstein’s view of] the sound human understanding gives one neither a final and unambiguous moral vocabulary nor an algorithm for choice under ethical uncertainty. In the sound human life there is still an abundance of fundamental moral struggle, and no promise that easy answers, or any at all, will be forthcoming.' 71

It seems clear that Wittgenstein believed that there was tremendous value in being aware of one's language-games, and in avoiding being trapped by the implications of any particular region of grammar. This is not to say that Wittgenstein thought that we needed to develop a thoroughgoing critical analysis of our forms of life. As James Tully has argued, such a comprehensive critical grounding is neither necessary nor possible. 72 Rather, the goal is to strike the difficult balance between the inescapable necessity of having and acting on beliefs and the intellectual rigor and flexibility that come from never believing that things must be as we currently think they are.

On this reading, I make my normative choices based on my form of life. Since language and meaning are rooted in family resemblance and social convention, it seems possible and 
perhaps even likely that my form of life will contain internal contradictions and currents of self-criticism. ${ }^{73}$ Thus, my form of life will be a source of both certainty and ongoing critical reflection. A permanent danger is that I will become captured by some part of my language-games and come to believe that things must be one way, ignoring the contradictory evidence from elsewhere in my form of life. A primary purpose of Wittgenstein's work was to assemble reminders to help me avoid such entanglements and live my form of life with my eyes open to its plurivocity and internal complexity. ${ }^{74}$ This does not commit me to any particular moral or political position - at the end of the day I will have to act, and my actions will be based on some compromise among my various beliefs. I have no special duty to try to give each belief the same influence, and I have no special duty to moderate my decisions because I recognize that other people have different beliefs. Of course I may decide to do just those things because they are called for by my beliefs, but I may equally well decide not to do them, for the same reason.

I may come across (or be forced by circumstance to live with) people with a very different form of life. The attitudes and actions I take towards these people are determined by my form of life, and to some extent by theirs - an attack by them may give rise to retaliation on my part, when my opening move would otherwise have been peaceful. There may be a great deal of room for discussion and negotiation between our forms of life, or relatively little. Whatever efforts we make towards solving the problems of plurality will necessarily be determined by the substances and interactions of our forms of life.

If I happen to adopt a Wittgensteinian epistemology, or endorse irrealist value pluralism, that viewpoint can tell me nothing about how I am to approach these others. Each time I 
turn to epistemology to tell me what to think or do, it directs me back to my form of life, to the practices and beliefs of my community, in all their tangled glory.

Livingston and Pohlhaus-and-Wright redux

Above I suggested that there are problems with Livingston's claim that Wittgenstein leads us to criticize reified concepts and power structures, and with Pohlhaus' and Wright's claim that we can only have an adequate sense of ourselves if we create political and social conditions of equality for all who share with us 'our' form of life. As I also mentioned above, it helps to start by recognizing that both positions are rooted in a conventionalist reading of Wittgenstein, though both try to problematize that reading as a way of avoiding the errors they perceive in the work of others. As I have argued in the intervening sections, I believe that Livingston and Pohlhaus and Wright are mistaken in their claim that the conventionalist reading, without adequate disclaimers, leads to either political or philosophical conservativism. That view, I have claimed, rests on an implausibly and unnecessarily rigid view of the concept of a form of life, and the alleged conservativism of conventionalism is avoided by adopting a more plausibly flexible and complex conception. At the same time, the effort to link Wittgenstein either to a position of social criticism or to a commitment to political egalitarianism rests on a wishful confusion between what Wittgenstein's theory makes possible and what it makes obligatory. It is certainly true, as Livingston argues, that Wittgenstein's analysis of the instability and contingency of our concepts provides us with a tool to criticize reification, but only if we wish to do so. Similarly, it is certainly true that recognizing the role that minority perspectives play in our form of life may lead us to value them more, but that impulse may also be overridden by the practical need to act now upon our admittedly inadequate ideas and beliefs. Without a much more complete 
Habermasian argument about why I should treat all positions that are comprehensible as worthy of equal consideration (Are there really no comprehensible positions that I can reject out of hand as having been fully investigated and disproved? Must I provide an equal public forum for the flat-Earthers?), that remains for Wittgensteinians merely a possibility, not a new duty revealed by the Philosophical Investigations.

Theory and therapy together again

I also suggested above that both the theory and the therapy schools of Wittgenstein interpretation should agree with the position that Wittgenstein's philosophy has no effects on normative or political life whatsoever. We are now in a position to see why that is so. As I have argued in the interim, if it is true that the best reading of Wittgenstein is as a conventionalist, then his philosophy has no normative or political consequences because the theory itself denies that our conventions must have any particular contents. (Theory readings that see Wittgenstein as a Pyrrhonian skeptic of some kind should come to the same position.) Similarly, it seems obvious that therapy readings - whose main point is that Wittgenstein's writing does not make positive assertions about philosophy - are thereby barred from laying claim to any particular normative consequences emerging from Wittgenstein's writings. Writing that does not make claims about philosophy or human nature or knowledge cannot give rise to or reveal a moral duty or obligation (though of course it may incidentally spur individuals to all sorts of transformations). But in fact the therapy readings come one step closer to the neutral interpretation. Let us assume that the therapy readings are entirely correct - that Wittgenstein's writings were not intended to convey positive theses, and that in fact they do not do so. Rather, they help us learn to be less attached to the project of seeking universal, apodictic explanations of our experience. Indeed, they are so successful that philosophy, though it springs eternal, is a 
malady that each of us can treat relatively easily. How then are we likely to behave? More to the point, what basis do those who put forward the therapy reading have for predicting how we will behave? If they make particular positive claims (We will all be peaceful! We will all be selfish Hobbesians!), they contradict themselves by assuming theories about human nature that are not in evidence. If they say that our behavior will largely be determined by our prior socialization and forms of life, they simply become weak conventionalists (which in my view is the right position anyway, but that is a different argument). Really, their only choice is to say nothing about this question whatsoever: they have no basis for making any predictions at all about what effects reading and understanding Wittgenstein's work would have on us. From their perspective, there is no reason to believe that Wittgenstein's work would have any particular effect. Thus, whether we approach Wittgenstein from a theoretical reading or a therapeutic reading, the conclusion is the same: his philosophy has no normative or political consequences at all.

Conclusion: pluralism

How does all of this now relate back to pluralism? Remember that the concern of the value pluralists is how we can live together despite the fact that we appear to have value systems that are incompatible, in the sense that they cannot be put into place simultaneously, and incommensurable, in the sense that we have no way to decide which system is the best. If we are committed to avoiding chaos (the inability to make laws and policies due to disagreement) and also to avoiding oppression (a situation in which someone is forced to obey laws that he or she rejects as immoral and unjust), the plurality of value judgments appears to pose a grave problem for social cooperation. 
Remember that in this article I am particularly concerned with irrealist value pluralism. If we come to believe empirical value disagreement is caused by the fact that moral values are in fact irreal, in the sense that they are contingent and context-relative, does that recognition do anything to help us deal with the problems of pluralism? Our assessment of the literature on the political implications of the conventionalist reading of Wittgenstein helps us see that the answer must be no. The fact of irrealist pluralism does not reveal a duty to toleration or egalitarianism because such duties are relative to forms of life, and there is no reason to believe that every form of life does or will contain them. Nor does the fact of pluralism reveal that we must all be Burkean conservatives, since moral irrealism, and the conventionalism implied by it, does not necessarily mean that forms of life are monolithic or hermetically sealed off from each other. To the extent that forms of life are internally complex and conflictual, and to the extent that they overlap and interpenetrate each other, their commands about how to live will be multiple and changeable. Finally, irrealist pluralism does not necessarily lead to nihilism, since my moral beliefs are not simply ornaments that I may discard at will. To the extent that they are constitutive of my personality and my understanding of the world, I will continue to be influenced by them even if I wholeheartedly accept that they are merely contingent and context-relative. However, just as Wittgenstein did not resolve the question of whether human nature is such that this kind of contextual relativism will slowly sap our moral wills, so too irrealist pluralism cannot put this doubt to rest. The truth about that question remains unknown.

Thus, working through the normative and political implications of Wittgenstein's philosophy helps us grasp the implications of irrealist pluralism: by itself, it apparently has none. Coming to believe that value is plural because it is context-relative has no particular 
consequences: we are merely left to make our way as best we can using our existing normative and political resources. Given limitations of space, I cannot discuss beyond a quick sketch how we might respond to the challenges of this value pluralism. It seems obvious that pluralism leaves open to us some avenues of cooperation. To the extent that individuals or ways of life contingently share some (or many) values, they will be able to cooperate on the basis of moral principle. Societies and individuals who do not find themselves in such substantive agreement would be able to pursue a Hobbesian modus vivendi - cooperation inspired by each participant's self-interest. Some societies would probably combine these two strategies, seeking principled agreement in some areas and a cooperation born of enlightened self-interest in others. With luck, perhaps those thin bases of cooperation could be modified or strengthened over time, by the creation of interpersonal and cultural ties, the emergence of institutions that many people value for different reasons, or a change in people's views due to a gradual convergence born of mutual respect. Thus, instead of the traditional philosophical goal of political cooperation bounded by moral obligations that all rational actors must acknowledge and obey, and instead of a mere Hobbesian ceasefire among mutually hostile parties, we could achieve a kind of layered pluralism, in which individuals and societies cooperate in a wide variety of ways, for a variety of reasons, some resting on moral duties, others on support for institutions, and yet others on various kinds of self-interest. There is much to be dissatisfied with in such a vision of politics, but that may be the world in which we find ourselves.

Notes

Earlier drafts of this article were presented at the 2004 meeting of the Northeast Political Science Association and the 2006 meeting of the American Political Science Association. I am 
grateful for the helpful comments of the other panelists and the discussants on those occasions. I would also like to thank Don Loeb, Pat Neal, Erin Ackerman and several anonymous reviewers for their extremely generous help in commenting on earlier drafts of this article.

1. See the helpful if now slightly dated bibliography in Cressida J. Heyes (ed.) The Grammar of Politics: Wittgenstein and Political Philosophy (Ithaca, NY and London: Cornell University Press, 2003).

2. J. C. Nyiri, 'Wittgenstein’s Later Work in Relation to Conservatism', in Wittgenstein and His Times, ed. B. F. McGuinness (Oxford: Blackwell, 1981).

3. Aryeh Botwinick, Wittgenstein, Scepticism, and Political Participation: An Essay in the Epistemology of Democratic Theory (Lanham, MD: University Press of America, 1985).

4. For example, Robert Fogelin, Wittgenstein, 2nd edn (London: Routledge, 1987).

5. Ernest Gellner, ‘The Gospel According to Ludwig’, The American Scholar 53 (1984): 24363.

6. For an exceptionally helpful and long-overdue survey of the range of Wittgenstein interpretation, see Guy Kahane, Edward Kanterian and Oskari Kuusela (eds) Wittgenstein and His Interpreters (New York: John Wiley \& Sons, 2007).

7. See ibid., as well as Alice Crary and Rupert Read (eds) The New Wittgenstein (London and New York: Routledge, 2000).

8. Ludwig Wittgenstein, Tractatus Logico-Philosophicus, trans. D. F. Pears and B. F. McGuinness (London and New York: Routledge, 1961), § 6.54.

9. See Phil Hutchinson and Rupert Read, ‘An Elucidatory Interpretation of Wittgenstein’s Tractatus: a Critique of Daniel D. Hutto's and Marie McGinn's Reading of Tractatus 6.54', International Journal of Philosophical Studies 14(1) (2006):1 -29. 
10. 'The world that we encounter in ordinary experience is one in which we are faced with choices between ends equally ultimate, and claims equally absolute, the realization of some of which must inevitably involve the sacrifice of others’: Isaiah Berlin, Four Essays on Liberty (Oxford and New York: Oxford University Press, 1969), p. 168.

11. For an excellent short bibliography, see William A. Galston, Liberal Pluralism: The Implications of Value Pluralism for Political Theory and Practice (Cambridge: Cambridge University Press, 2002), p. 5, n. 3.

12. See Berlin, Four Essays on Liberty; Isaiah Berlin and Bernard Williams, 'Pluralism and Liberalism: a Reply’, Political Studies 42(2) (1994): 306-9; Galston, Liberal Pluralism: The Implications; William A. Galston, 'Liberal Pluralism: a Reply to Talisse’, Contemporary Political Theory 3 (2004): 140-7; John Gray, 'Where Pluralists and Liberals part Company’, International Journal of Philosophical Studies 6(1) (1998): 17-36; John Gray, Isaiah Berlin (Princeton, NJ: Princeton University Press, 1996); John Gray, Enlightenment's Wake: Politics and Culture at the Close of the Modern Age (London and New York: Routledge, 1995); Bernard Williams, ‘Introduction’, in Concepts and Categories: Philosophical Essays, ed. Isaiah Berlin (New York: Viking Press, 1979).

13. See Friedrich Nietzsche, On the Genealogy of Morality, trans. C. Diethe (Cambridge: Cambridge University Press, 1994).

14. See Richard Rorty, Contingency, Irony and Solidarity (Cambridge and New York: Cambridge University Press, 1989).

15. For arguments that pluralism does have some kind of normative consequences, see the work by Berlin, Galston and Gray cited above. For criticisms of that position, see Robert B. 
Talisse, ‘Can Value Pluralists be Comprehensive Liberals? Galston’s Liberal Pluralism’, Contemporary Political Theory 3 (2004): 127-39; Robert B. Talisse, ‘Two-Faced Liberalism: John Gray’s Pluralist Politics and the Reinstatement of Enlightenment Liberalism', Critical Review 14(4) (2000): 441-58; William M. Curtis, 'Liberals and Pluralists: Charles Taylor vs John Gray’, Contemporary Political Theory 6(1) (2007): 86-107; Matthew J. Moore, 'Pluralism, Relativism, and Liberalism', Political Research Quarterly 62(2) (June 2009): 244-56.

16. Wittgenstein writes: 'We picture facts to ourselves’ (Tractatus, § 2.1): ‘A picture is a model of reality’ (Tractatus, § 2.12); 'In a picture, the elements of the picture are the representatives of objects’ (Tractatus, § 2.131).

17. 'The fact that the elements of a picture are related to one another in a determinate way represents that things are related to one another in the same way. Let us call this connexion of its elements the structure of the picture, and let us call the possibility of this structure the pictorial form of the picture’ (Wittgenstein, Tractatus, § 2.15).

18. Ludwig Wittgenstein, Philosophical Investigations, $3^{\text {rd }}$ edn, trans. G. E. M. Anscombe (Englewood Cliffs, NJ: Prentice-Hall, 1958), § 47.

19. There is a possible source of confusion here. Wittgenstein is not saying that there are no atomic simples, because, following his argument, we have no idea one way or the other. Rather than making that ontological claim, Wittgenstein is making the epistemological point that we are permanently unable to identify simples. But, given that inability, a strategy of explaining language by reference to them becomes impossible. Thus, although his argument is basically epistemological, it has ramifications for how we conceptualize ontology. (In this as in many other things, Wittgenstein is very much the heir of Kant.) 
20. Wittgenstein, Philosophical Investigations, § 80.

21. ibid., § 87.

22. 'What any picture, of whatever form, must have in common with reality, in order to be able to depict it - correctly or incorrectly - in any way at all, is logical form, i.e. the form of reality’ (Wittgenstein, Tractatus, § 2.18).

22. Wittgenstein, Philosophical Investigations, § 65.

23. ibid., § 50. See also: 'Like everything metaphysical, the harmony between thought and reality is to be found in the grammar of the language': Ludwig Wittgenstein, Zettel, trans. G. E. M. Anscombe (Berkeley and Los Angeles: University of California Press, 1970), § 55.

24. Wittgenstein, Philosophical Investigations, § 496.

25. ibid., § 43. What cases does Wittgenstein intend to exclude from this definition? At least one seems to be the use of 'meaningful' to convey emotional significance. For example, see his discussion of poetry at Wittgenstein, Philosophical Investigations, §§ 531-2.

26. Wittgenstein, Philosophical Investigations, § 10.

27. ibid., § 198.

28. ibid., § 201.

29. ibid., § 198.

30. For a discussion of Wittgenstein as contextualist, see R. A. Shiner, 'Wittgenstein and the Foundations of Knowledge', Proceedings of the Aristotelian Society 78 (1977): 103-24; R. A. Shiner, 'Foundationalism, Coherentism and Activism', Philosophical Investigations 3(3) (1980): 33-8. For a contemporary explanation and defense of epistemological contextu- 
alism, see Michael Williams, Problems of Knowledge: A Critical Introduction to Epistemology (Oxford: Oxford University Press, 2001).

31. Wittgenstein, Philosophical Investigations, § 217.

32. 'All testing, all confirmation and disconfirmation of a hypothesis takes place already within a system. And this system is not a more or less arbitrary and doubtful point of departure for all our arguments: no, it belongs to the essence of what we call an argument. The system is not so much the point of departure, as the element in which arguments have their life': Ludwig Wittgenstein, On Certainty, trans. D. Paul and G. E. M. Anscombe (New York: Harper \& Row, 1969), § 105.

33. 'The mythology may change back into a state of flux, the river-bed of my thoughts may shift. But I distinguish between the movement of the waters on the river-bed and the shift of the bed itself; though there is not a sharp division of the one from the other’: ibid., § 97.

34. ibid., § 141.

35. Wittgenstein, Tractatus, § 6.421.

36. ibid., § 7.

37. Ludwig Wittgenstein, 'A Lecture on Ethics’, Philosophical Review 74 (1965): 3-26 (1112).

38. Two arguments seem to delimit the space in which conflicts are possible or coherent. At one limit, Donald Davidson argues that if our alleged value systems are so different as to be mutually incomprehensible, we no longer have grounds for thinking that we are talking about the same thing; see Donald Davidson, 'On the Very Idea of a Conceptual Scheme', Proceedings of the American Philosophical Association XLVII (1974): 5-20. We can only 
disagree about values if both of us can recognize the other's position as being about what we, too, call values.

At the other limit, Mitchell Silver argues that if values are merely contingent constructs, there is no reason to think that they could never be reconciled; see Mitchell Silver, 'Irreconcilable Moral Disagreement', in Defending Diversity: Contemporary Philosophical Perspectives on Pluralism and Multiculturalism, ed. Lawrence Foster and Patricia Herzog (Cambridge, MA: University of Massachusetts Press, 1994). To claim that no reconciliation or commensuration could ever take place is bizarrely dogmatic - surely some chain of events could lead to it, though admittedly that may be very unlikely or impractically timeconsuming.

Thus, for irrealist value pluralism to be possible, there must be situations in which people who all recognize that they are talking about moral values, and each of whom recognizes the others' beliefs as moral values, are nonetheless unable to reach agreement about how to rank those values. At the same time, it would be wrong to say that these situations prove or even suggest that this inability to rank the various values is or must be permanent. Surely Silver is correct that, given the right circumstances, they could be resolved. That said, we can easily imagine situations in which prolonged efforts have failed to bring about agreement, and in which the changes that would make agreement possible seem so profound and unlikely that we would be justified in saying that the dispute is, for all practical purposes, currently irresolvable. While there is some danger of misunderstanding here, there is also a danger in Silver's position of mistaking the mere possibility of a reconciliation for the reasonableness of expecting one.

40. See Crary and Read, The New Wittgenstein. 
41. Alice Crary, ‘Wittgenstein’s Philosophy in Relation to Political Thought', in ibid.

42. ibid., p. 137.

43. ibid., p. 138.

44. Wittgenstein, Philosophical Investigations, § 10.

45. Gaile Pohlhaus and John R. Wright, 'Using Wittgenstein Critically: a Political Approach to Philosophy’, Political Theory 30(6) (2002): 800-27.

46. Paul Livingston, 'Wittgenstein, Kant and the Critique of Totality', Philosophy \& Social Criticism 33(6) (2007): 691-715.

47. ibid., 696.

48. ibid., 702.

49. Pohlhaus and Wright, 'Using Wittgenstein Critically', 801; internal citation omitted.

50. ibid., 810.

51. Livingston, 'Wittgenstein, Kant and the Critique of Totality', 709.

52. Pohlhaus and Wright, 'Using Wittgenstein Critically', 821.

53. ibid., 804.

54. See Livingston, 'Wittgenstein, Kant and the Critique of Totality’, 696.

55. Botwinick, Wittgenstein, Scepticism, and Political Participation, pp. 11-12.

56. Richard Eldridge, 'Wittgenstein and the Conversation of Justice', in The Grammar ofPolitics: Wittgenstein and Political Philosophy, ed. Cressida J. Heyes (Ithaca, NY and London: Cornell University Press, 2003), pp. 127-8.

57. Lawrence M. Hinman, ‘Can a Form of Life be Wrong?’, Philosophy 58 (1983): 339-51 (351). 
58. Linda M. G. Zerilli, 'Wittgenstein: Between Pragmatism and Deconstruction', in The Legacy of Wittgenstein: Pragmatism or Deconstruction, ed. Ludwig Nagl and Chantal Mouffe (Frankfurt: Peter Lang, 2001), p. 41.

59. Nyiri, ‘Wittgenstein’s Later Work’, p. 58.

60. ibid., pp. 60-1.

61. Notably Hannah Pitkin, Wittgenstein and Justice: On the Significance ofLudwig Wittgenstein for Social and Political Thought (Berkeley: University of California Press, 1972); Andrew Lugg, 'Was Wittgenstein a Conservative Thinker?', Southern Journal of Philosophy 23(4) (1985): 465-74; and Richard E. Flathman, Willful Liberalism: Voluntarism and Individuality in Political Theory and Practice (Ithaca, NY and London: Cornell University Press, 1992).

62. See Lugg, 'Was Wittgenstein a Conservative Thinker?’.

63. Flathman, Willful Liberalism, p. 58.

64. See Richard Rorty, Philosophy and the Mirror ofNature (Princeton, NJ: Princeton University Press, 1979), and Rorty, Contingency, Irony and Solidarity. Richard Rorty, Consequences of Pragmatism: Essays 1972-1980 (Minneapolis: University of Minnesota Press, 1982).

65. See, for example, Richard Rorty, Achieving Our Country: Leftist Thought in TwentiethCentury America (Cambridge, MA and London: Harvard University Press, 1998). See also the similar position expressed in Gianni Vattimo, Nihilism \& Emancipation: Ethics, Politics, \& Law, trans. W. McCuaig (New York: Columbia University Press, 2004). 66. Gellner, 'The Gospel According to Ludwig', 251. 67. ibid., 254. 
68. For example, see Nietzsche, Genealogy.

69. This position is famously elaborated in Plato, The Republic of Plato, trans. F. M. Cornford (London, Oxford and New York: Oxford University Press, 1941).

70. In particular, see David Owen, 'Genealogy as Perspicuous Representation', in The Grammar ofPolitics: Wittgenstein and Political Philosophy, ed. Cressida J. Heyes (Ithaca, NY and London: Cornell University Press, 2003). and Paul Johnston, Wittgenstein and Moral Philosophy (London: Routledge, 1989).

71. James C. Edwards, Ethics without Philosophy: Wittgenstein and the Moral Life (Tampa: University Presses of Florida, 1982), p. 220.

72. James Tully, 'Wittgenstein and Political Philosophy: Understanding Practices of Critical Reflection', Political Theory 17(2) (1989): 172-204.

73. This point is made explicitly by both Sabina Lovibond, Realism and Imagination in Ethics (Oxford: Basil Blackwell, 1983) and Naomi Scheman, 'Forms of Life: Mapping the Rough Ground', in The Cambridge Companion to Wittgenstein, ed. Hans Sluga and David G. Stern (Cambridge: Cambridge University Press, 1996).

74. Hannah Pitkin puts the point beautifully: 'Instead of retreating to a last island of certainty, Wittgenstein's later philosophy examines the craving for certainty itself, and concludes that we are, after all, able to live on the sea’ (Pitkin, Wittgenstein and Justice, p. 337). 